\title{
IDENTIFIKASI RANCANG BANGUN ALAT UKUR DAN SISTEM KENDALI KADAR TOTAL DISSOLVED SOLID (TDS) PADA AIR BERBASIS MIKROKONTROLER
}

\author{
Mohammad Hafiz Hersyah ${ }^{1}$, Darman Harry Dinata ${ }^{2}$, Firdaus ${ }^{3}$ \\ 1,2 Jurusan Sistem Komputer Fakultas Teknologi Informasi Universitas Andalas \\ Jln. Kampus Limau Manis Kota Padang 25163 \\ ${ }^{3}$ Jurusan Teknik Elektro Politeknik Negeri Padang \\ Jln. Kampus Limau Manis Kota Padang 25163 \\ mhafiz@fti.unand.ac.id ${ }^{1)}$
}

\begin{abstract}
ABSTRAK
Dalam penelitian ini, Alat ukur kadar total dissolved solid (TDS) pada air dibuat dengan menggunakan sensor konduktivitas yang mana sensor ini bekerja dengan menggunakan prinsip konduktansi yaitu kemampuan larutan dalam mengantarkan arus listrik, jadi semakin banyak kandungan zat terlarut yang terdapat pada air maka semakin besar juga nilai konduktansinya. Hasil pengukuran dari sensor akan dibandingkan dengan nilai setpoint selanjutnya akan digunakan untuk menghidupkan pompa booster yang akan melakukan proses filterisasi guna menurunkan kadar TDS air dengan menggunakan membran $R O$. Kinerja dari pembacaan sensor saat pertama kali digunakan dipengaruihi oleh waktu dimana sistem membutuhkan 3 menit untuk mencapai keadaan stabil, sedangkan untuk sistem secara keseluruhan dipengaruhi oleh banyaknya volume air yang aka diturunkan kadar TDS nya. Hasil pengujian disajikan dalam bentuk grafik perubahan kadar TDS air terhadap waktu, didapatkan perbedaan waktu yang dibutuhkan untuk menurunkan kadar TDS sebesar 15 ppm untuk air bervolume 1 liter selama 6 menit, air bervolume 2 liter selama 10 menit dan untuk air bervolume 3 liter selama 16 menit.
\end{abstract}

Kata Kunci: Total Dissolved Solid, Pompa Boster, Membran RO (Reverse Osmosis)

\begin{abstract}
In this study, the total dissolved solid (TDS) in water was made using conductivity sensor which the sensor works by using the principle of conductance that is the ability of the solution in delivering the electric current, so the more content of solute contained in the water the greater also the value of its conductance. The measurement results of the sensor will be compared with the next setpoint value will be used to turn on the booster pump which will do the filtering process in order to decrease the TDS water content by using RO membrane. The performance of sensor readings when first used is boosted by the time at which the system takes 3 minutes to reach a stable state, while for the whole system is influenced by the volume of water that will decrease its TDS level. The test results are presented in the form of graph of change of TDS water content over time, the difference of time required to decrease the TDS level by 15 ppm for 1 liter of water for 6 minutes, 2 liter of water for 10 minutes and for 3 liters of water for 16 minutes.
\end{abstract}

Keywords : Total Dissolved Solid, Pompa Boster, Membran RO (Reverse Osmosis)

\section{PENDAHULUAN}

Air memiliki peranan yang sangat penting bagi kehidupan di bumi, baik itu untuk manusia, hewan maupun tumbuhan. Ada beberapa parameter yang menentukan air sehat di antaranya bisa diketahui dari parameter fisik seperti airnya tidak berwarna, tidak berbau, bebas bakteri dan kuman. Selain itu TDS (Total Dissolved Solid) merupakan salah satu faktor yang juga penting, dimana TDS adalah total atau jumlah kandungan partikel terlarut yang terdapat dalam air. Hal ini dikarenakan air merupakan pelarut universal yang mudah menyerap dan melarutkan berbagai partikel yang ditemuinya. Oleh karena itu pasti setiap air mengandung partikel terlarut, Bisa berupa partikel padatan/logam, misal: besi, aluminium, tembaga, mangan dan lain lain, maupun partikel non padatan seperti mikro organisme.

Sebagian besar ekosistem perairan yang melibatkan ikan dapat mentolerir tingkat TDS 
maksimal hanya 1000 ppm [1]. Peningkatan kadar TDS yang sangat tinggi dapat meningkatkan penyakit, menurunkan tingkat pertumbuhan ikan, serta penurunan reproduksi ikan, bahkan dapat membunuh ikan secara langsung. Sedangkan kadar TDS yang terlalu rendah akan menyebabkan berkurangnya kandungan mineral alami pada air yang sangat dibutuhkan oleh plankton, yang mana plankton merupakan makanan alami bagi ikan.

Pada saat ini alternatif yang dilakukan oleh para pecinta ikan hias di akuarium, untuk mengetahui dan mengatur kadar TDS air dapat dilakukan dengan cara menggunakan alat ukur TDSMeter secara berkala dan membersihkan akuarium serta menukar dengan air yang baru guna menurunkan kadar TDS air. Cara ini kurang efektif karena kadar TDS air sangat mudah berubah sesuai dengan keadaan lingkungan di sekitarnya, sebagai contoh air yang sudah lama tidak diganti, pemberian pakan ikan dan kotoran ikan juga akan mempengaruhi kadar TDS air. Oleh sebab itu dirancanglah sebuah alat yang bisa mendeteksi kadar TDS air dengan menggunakan sensor konduktivitas yang memanfaatkan prinsip konduktansi yaitu kemampuan air untuk menghantarkan arus listrik, dimana nilai konduktansi ini akan berbanding lurus dengan banyaknya kandungan zat padat terlarut yang terdapat pada air [2]. Hasil pembacaan dari sensor diproses pada mikrokontroler lalu dikonversikan menjadi nilai kadar TDS. Nilai kadar TDS akan digunakan sebagai parameter untuk mengontrol pompa, dimana pompa akan aktif jika kadar TDS yang terdeteksi oleh sensor melebihi nilai setpoint yang diinputkan melalui keypad dan akan berhenti jika nilainya telah sama dengan setpoint. Selanjutnya pompa akan dihubungkan ke Membran RO (Membran Reverse Osmosis) yang melakukan proses filterisasi air guna menurunkan kadar TDS air

\section{TINJAUAN PUSTAKA}

\section{A. Total Dissolved Solid (TDS)}

Total Dissolved Solid (TDS) merupakan banyaknya jumlah zat padat terlarut yang terdapat pada air. Hal ini disebabkan karna air merupakan pelarut universal yang sangat mudah untuk menyerap dan melarutkan berbagai partikel yang ditemuinya. Pada umumnya zat yang terlarut dalam air harus bisa melalui saringan yang berdiameter 2 micrometer $\left(2 \times 10^{-6} \text { meter }\right)^{[3]}$.

Sumber utama bagi TDS dalam perairan adalah limpahan dari pertanian, limbah rumah tangga, industri dan segala sesuatu yang dilalui oleh air. Untuk-unsur kimia yang paling umum terlarut adalah kalsium, fosfat, nitrat, natrium, kalium dan klorida.. Untuk sumber utama padatan total terlarut yang alami berasal dari pelapukan dan pelarutan batu, tanah, kayu, dll.

Kadar TDS yang sangat tinggi tidaklah baik, bagi ekosistem perairan khususnya ikan, kadar TDS sangat berpengaruh terhadap peningkatan dan pertumbuhan ikan. Contohnya, air pada akuarium yang tidak ditukar atau disaring, lama-kelamaan akan menyebabkan peningkatan kadar TDS yang nantinya akan berpengaruh kepada kelangsungan hidup ikan, bahkan jika kadar TDS terlalu tinggi akan mengakibatkan peningkatan penyakit, penurunan reproduksi ikan, bahkan membunuh ikan secara langsung. Jika kadar TDS terlalu rendah akan menyebabkan berkurangnya kandungan mineral yang sangat dibutuhkan oleh plankton yang merupakan makanan alami bagi ikan, yang akan mempengaruhi pertumbuhan dan perkembangan ikan secara tidak langsung. Pada Tabel 2.1 ditunjukkan kadar TDS air untuk beberapa jenis ikan.

Tabel 1. Kadar TDS Air dan Jenis Ikan

\begin{tabular}{|c|c|c|}
\hline Kadar TDS & PPM & Jenis Ikan \\
\hline Rendah & $0-75$ & $\begin{array}{c}\text { Discus/Apistogramma } \\
\text { sp }\end{array}$ \\
\hline $\begin{array}{l}\text { Cukup } \\
\text { Tinggi }\end{array}$ & $75-150$ & Angelfish, Severums \\
\hline Tinggi & $150-300$ & $\begin{array}{c}\text { Central American } \\
\text { Cilchlids }\end{array}$ \\
\hline $\begin{array}{l}\text { Sangat } \\
\text { Tinggi }\end{array}$ & $300+$ & $\begin{array}{c}\text { African Chil/Marine } \\
\text { Fish }\end{array}$ \\
\hline
\end{tabular}

\section{B. Membran RO (Reverse Osmosis)}

Membran RO merupakan suatu filter pemisah air murni. Membran RO ini mampu menghasilkan sekitar 90\% air baku menjadi air murni. Biasanya Membran RO ini terdiri atas beberapa lapisan saringan yang berdiameter sangat kecil hingga 0,0001 mikron ${ }^{[3]}$ seperti terlihat pada Gambar 1 .

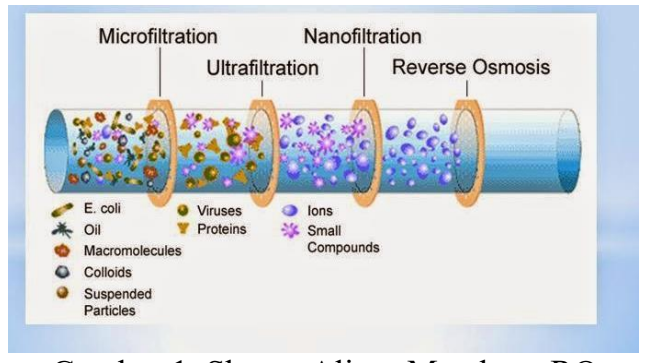

Gambar 1. Skema Aliran Membran RO

Tabel 2 dibawah ini memaparkan spesifikasi umum dari membrane RO

Tabel 2. Spesifikasi Membran RO

\begin{tabular}{|l|l|}
\hline Kapasitas & $50 \mathrm{gpd}$ \\
\hline Tekanan Normal & $80 \mathrm{psi}$ \\
\hline Tekanan Max & $125 \mathrm{psi}$ \\
\hline Suhu Max & $45 \mathrm{C}$ \\
\hline
\end{tabular}




\begin{tabular}{|l|l|}
\hline Penyaringan & $93 \%$ \\
\hline Diameter saringan & 0,0001 mikron \\
\hline
\end{tabular}

\section{Prinsip Kerja Reverse Osmosis}

Reverse Osmosis merupakan kebalikan dari Osmosis ${ }^{[4]}$. Secara teori larutan yang memiliki konsentrasi zat pencemar terlarut yang tinggi akan mengalir ke yang rendah, untuk mencegah terjadinya pencampuran maka diberi batas berupa Osmosis Membran Semipermeable. Ini merupakan suatu membran yang hanya bisa dilalui oleh molekul air murni saja dan menyaring zat terlarut yang terdapat pada air.

Proses Osmosis disini yaitu proses mengalirnya larutan yang memiliki konsentrasi rendah menuju larutan yang memiliki konsentrasi tinggi. Proses Osmosis seperti terlihat pada Gambar 2 akan mengakibatkan naiknya permukaan larutan yang memiliki konsentrasi tinggi dibandingkan dengan yang memiliki konsetrasi rendah.

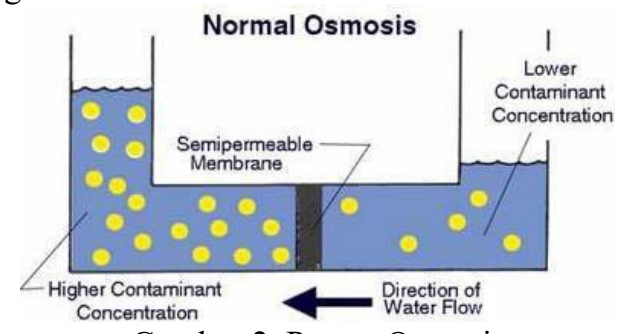

Gambar 2. Proses Osmosis

Proses dari Reverse Osmosis merupakan kebalikan dari proses Osmosis yaitu dengan cara memberikan tekanan tinggi pada larutan yang berkonsentrasi tinggi menuju larutan berkontrasi rendah maka akan menyebabkan kandungan zat terlarut pada air akan tersaring oleh membran semipermeable, dikarenakan Membran semipermeable tidak dapat dilalui dan ditembus oleh zat terlarut padat, dan hanya molekul air saja yang bisa melaluinya karena ukuran sangat kecil. Melalui proses Reverse Osmosis seperti yang ditunjukkan pada Gambar 3 kita bisa menurunkan zat terlarut yang terdapat pada air.

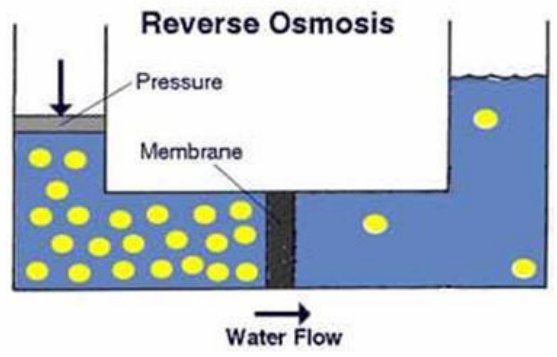

Gambar 3. Proses Reverse Osmosis

\section{TDS Meter}

TDS Meter adalah alat untuk mengukur total partikel zat padat terlarut di air ${ }^{[3]}$.

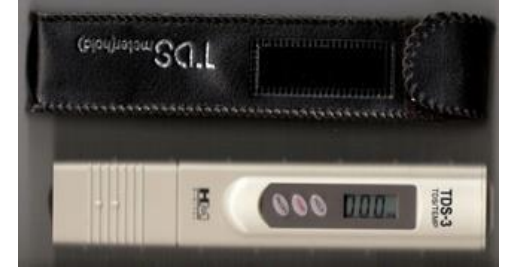

Gambar 4. TDS Meter

Alat ini bisa mengukur berapa jumlah padatan yang terlarut didalamnya dalam satuan ppm $(\mathrm{mg} / \mathrm{L})$ yang ditunjukkan berupa angka digital di displaynya. Cara kerja alat ini cukup sederhana yaitu dengan cara mencelupkan kedalam air yang akan diukur (kira-kira kedalaman $5 \mathrm{~cm}$ ) dan secara otomatis alat bekerja mengukur kadar TDS pada air. Pada saat pertama dicelupkan angka yang ditunjukkan oleh display masih berubah-ubah, untuk mendapatkan hasil yang akurat dapat menunggu sekitar 2 sampai 3 menit sampai angka digital pada TDS meter stabil.

\section{E. Sensor Konduktivitas}

Sensor konduktivitas ini memiliki 3 pin yaitu vcc, gnd dan pin output. Sensor ini membutuhkan Vsuplay sebesar 5v Dc dan menghasilkan output analog dalam rentang 0-5 v. Pada ujung sensor ini terdapat 2 buah probe yang terbuat dari bahan stainles steel.

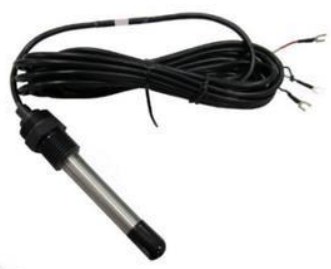

Gambar 5. Sensor Konduktivitas

Sensor konduktivitas merupakan sensor yang bekerja dengan memanfaatkan prinsip konduktansi, dimana prinsip konduktasi (Electrical Conductivity) adalah kemampuan suatu larutan dalam mengantarkan arus listrik [2]. Prinsip ini merupakan salah satu metode yang bisa digunakan untuk menentukan kadar kandungan zat terlarut pada suatu larutan (air).

Konsentrasi ion (kandungan zat terlarut) di dalam larutan akan berbanding lurus dengan kemampuan larutan dalam menghantarkan arus lisrtik, jadi semakin besar kandungan zat terlarut pada air, maka akan semakin besar kemampuan larutan dalam menghantarkan arus listrik dan sebaliknya.

\section{F. Pompa Booster RO}

Pompa booster ini diperlukan karena Membran RO memiliki diameter yang sangat kecil sehingga dibutuhkan air bertekanan tinggi supaya bisa melewati Membran RO, akan tetapi antara 
kemampuan Membran RO dan kemampuan dari pompa booster haruslah seimbang [5]. Maksudnya adalah jika digunakan Membran RO 50 gpd (galon per day) maka harus digunakan pompa booster 24 volt, ini disebabkan karena Membran RO akan bekerja optimal jika tekanan yang diberikan sesuai dengan kemampuan membran. Apabila tekanan yang diberikan lebih kecil maka Membran RO tidak akan bekerja maksimal karena air kurang mampu melewati membran, sedangkan apabila tekanan yang diberikan terlalu tinggi akan menyebabkan Membran RO menjadi rusak dan robek.

Pompa booster seperti terlihat pada Gambar 6 sudah dilengkapi dengan adaptor yang berfungsi untuk mengubah tegangan AC menjadi tegangan DC yang lebih rendah yang mana disini menjadi 24 volt.

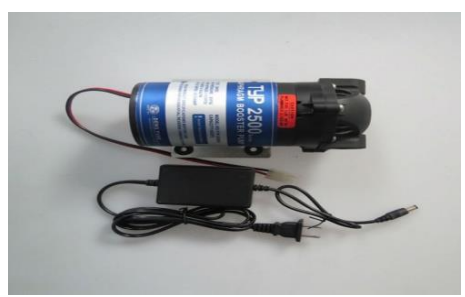

Gambar 6. Pompa Booster

Tabel 3. Spesifikasi Pompa Booster

\begin{tabular}{|c|c|}
\hline Input & $24 \mathrm{~V} \mathrm{DC}$ \\
\hline Tekanan Normal & $80 \mathrm{psi}$ \\
\hline Tekanan Maksimum & $125 \mathrm{psi}$ \\
\hline Aliran saat $80 \mathrm{psi}$ & 0.6 liter per menit \\
\hline Kapasitas & $50 \mathrm{gpd}$ \\
\hline
\end{tabular}

\section{G. Matrix Keypad $4 * 4$}

Keypad berfungsi sebagai interface antara perangkat (mesin) elektronik dengan manusia atau dikenal dengan istilah HMI (Human Machine Interface). Matrix keypad $4 \times 4$ merupakan salah satu contoh keypad yang dapat digunakan untuk berkomunikasi antara manusia dengan mikrokontroler. Disini digunakan untuk menginputkan nilai setpoint sistem.

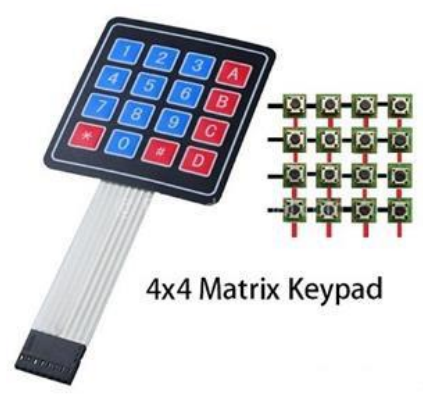

Gambar 7. Matrix Keypad 4*4

Sisi baris dari matrix keypad ditandai dengan nama Row1, Row2, Row3 dan Row4 kemudian sisi kolom ditandai dengan nama Col1, Col2, Col3 dan Col4. Sisi input atau output dari matrix keypad $4 \times 4$ ini tidak mengikat, dapat dikonfigurasikan kolom sebagi input dan baris sebagai output atau sebaliknya.

\section{H. Sistem Kontrol}

Sistem kontrol mempunyai pengertian sebagai suatu sistem yang dapat mengendalikan, mengatur, memerintahkan dan mengontrol sebuah alat untuk melakukan sesuatu. Secara teori sistem kontrol merupakan susunan dari beberapa komponen yang disusun sedemikian rupa sehingga mampu dan bisa mengatur sistemnya sendiri atau sistem di luarnya. Sistem kontrol ini mempunyai hubungan timbal balik antara komponennya sehingga membentuk konfigurasi sistem yang memberikan suatu hasil yang dikehendaki berupa respon ${ }^{[6]}$.

\section{Liquid Crystal Display (LCD)}

Liquid Crystal Display (LCD) adalah salah satu komponen elektronika yang berfungsi sebagai penampil data yang sangat efekitf dalam suatu sistem elektronik ${ }^{[7]}$.

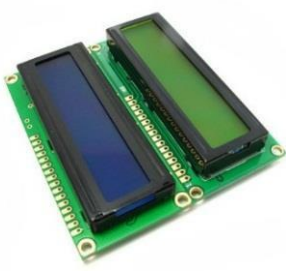

Gambar 8. LCD

\section{J. Regresi Polinomial}

Regresi polinomial merupakan salah satu pendekatan yang digunakan untuk mencari dan menentukan fungsi yang paling sesuai dengan kumpulan titik titik data.

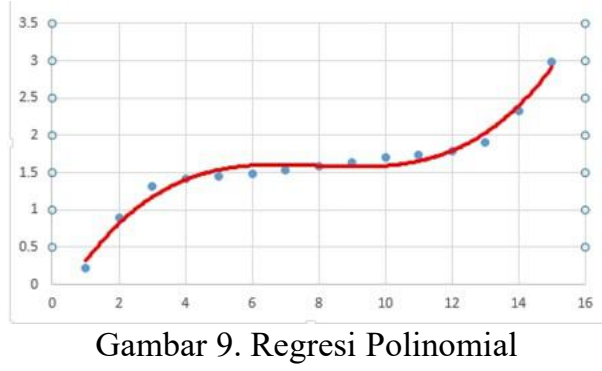

Untuk mencari persamaan polinomial orde $\mathrm{N}$ dapat dicari dengan menggunakan hubungan sebagai berikut :

$\left|\begin{array}{ccccc}n & \sum x_{i} & \sum x_{i}^{2} & \cdots & \sum x_{i}^{n} \\ \sum x_{i} & \sum x_{i}^{2} & \sum x_{i}^{3} & \cdots & \sum x_{i}^{n+1} \\ \sum x_{i}^{2} & \sum x_{i}^{3} & \sum x_{i}^{4} & \cdots & \sum x_{i}^{n+2} \\ \vdots & \vdots & \vdots & \ddots & \vdots \\ \sum x_{i}^{n} & \sum x_{i}^{n+1} & \sum x_{i}^{n+2} & \cdots & \sum x_{i}^{n+n}\end{array}\right| \begin{gathered}a \\ b \\ c \\ \vdots \\ \vdots\end{gathered}|=| \begin{gathered}\sum y_{i} \\ \sum x_{i} \cdot y_{i} \\ \sum x_{i}^{2} \cdot y_{i} \\ \vdots \\ \sum x_{i}^{n} \cdot y_{i}\end{gathered} \mid$


Berikut merupakan beberapa algoritma dalam mencari nilai regresi polinomial :

- Tentukan $\mathrm{N}$ titik data yang diketahui dalan (Xi,Yi) untuk $\mathrm{i}=1,2,3, \ldots, \mathrm{N}$

- Hitungnilai nilai yang berhubungan dengan jumlahan data untuk mengisi matrik normal

- Hitung nilai koefisien a,b,c,d dengan menggunakan

\section{METODE}

\section{A. Jenis Penelitian}

Penelitian Tugas Akhir ini merupakan jenis Experimental Research (penelitian percobaan). Dalam Experimental Research, subjek penelitian merupakan air yang akan diturunkan kadar TDSnya.

\section{B. Rancangan Penelitian}

Rancangan penelitian berisi tahapan yang akan dilakukan selama penelitian, dimulai dari identifikasi masalah hingga dokumentasi penelitian Tugas Akhir. Tahapan lebih rinci dalam penelitian Tugas Akhir ditunjukan pada diagram metodologi penelitian.

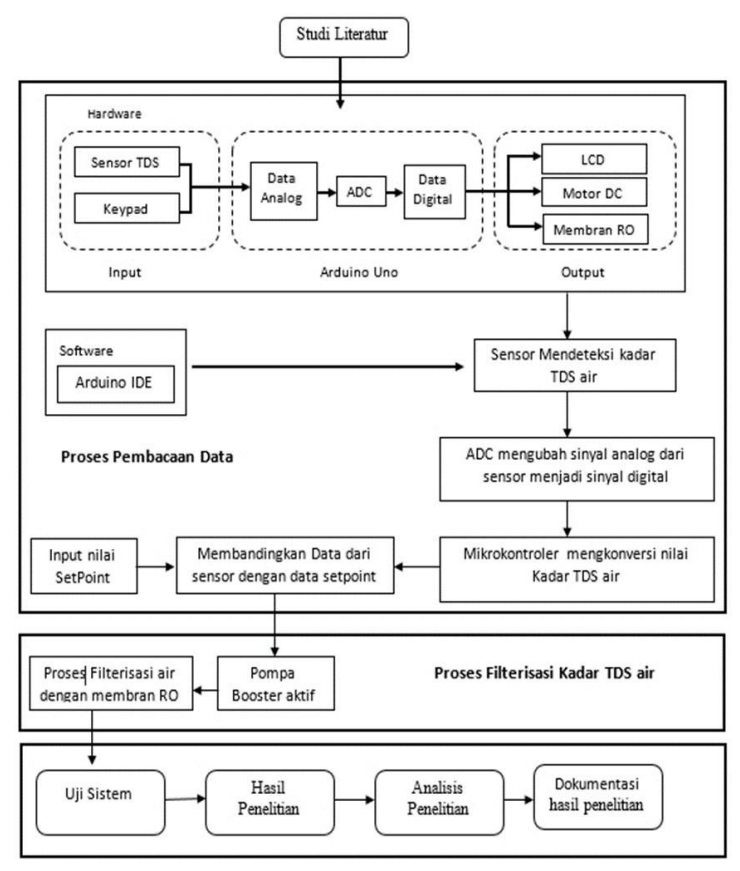

Gambar 9. Metode Penelitian

Berikut pada gambar 10 merupakan blok diagram sistem kontrol sistem yang dibuat.

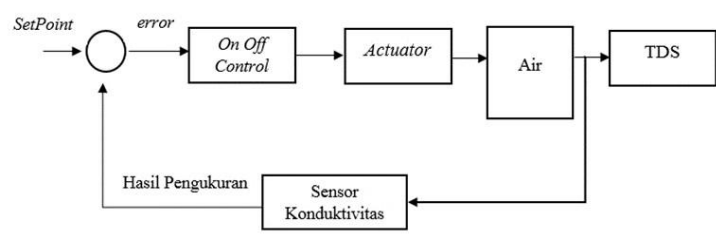

Gambar 10. Blok Diagram Sistem Kontrol

\section{Rancangan Hardware}

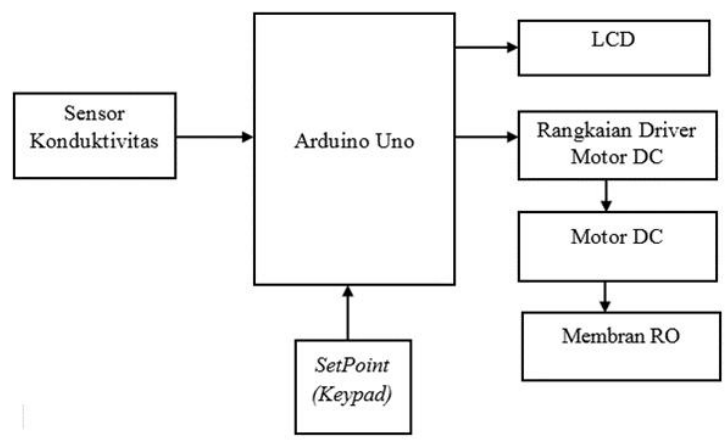

Gambar 11. Blok Diagram Perancangan Sistem

Sensor konduktivitas akan mendeteksi dan mengukur nilai TDS air, nilai dari sensor dikirim dan diproses pada mikrokontroler arduino uno, selanjutnya nilai dari sensor akan dibandingkan dengan nilai setpoint high dan setpoint low yang diinputkan melalui keypad, Jika nilai kadar TDS yang dideteksi sensor lebih besar dari nilai Setpoint high maka rangkaian driver motor DC akan mengaktifkan pompa booster dan membran RO akan melakukan proses filterisasi. Selanjutnya pompa akan mati jika nilai kadar TDS air yang telah melalui proses filterisasi dan terdeteksi sensor lebih kecil daripada nilai Setpoint low. Nilai perubahan kadar TDS yang dideteksi sensor dan setpoint akan ditampilkan pada LCD.

\section{Rancangan Software}

Sistem dimulai dengan inisialisasi sistem yaitu penentuan pin-pin input dan output, lalu sensor akan mulai membaca data berupa nilai TDS air dan juga membaca inputan data setpoint high dan setpoint low yang diinputkan melalui keypad.

Setelah didapatkan data berupa nilai TDS air serta nilai setpoint high dan setpoint low maka akan ditampilkan pada LCD. Selanjutnya sistem akan membandingan nilai TDS air dari sensor dengan setpoint high yang mana jika nilai sensor lebih besar dari setpoint high maka pompa booster aktif yang akan melakukan proses filterisasi untuk menurunkan kadar TDS air dengan menggunakan Membran RO sebagai Filternya, nilai TDS air yang telah melalui proses filterisasi ini akan dicek nilainya secara terus menerus dan perubahan nilai kadar/TDS air serta nilai setpoint akan ditampilkan pada LCD. Selanjutnya jika nilai kadar TDS air telah kecil dari nilai setpoint low maka pompa booster akan berhenti. 


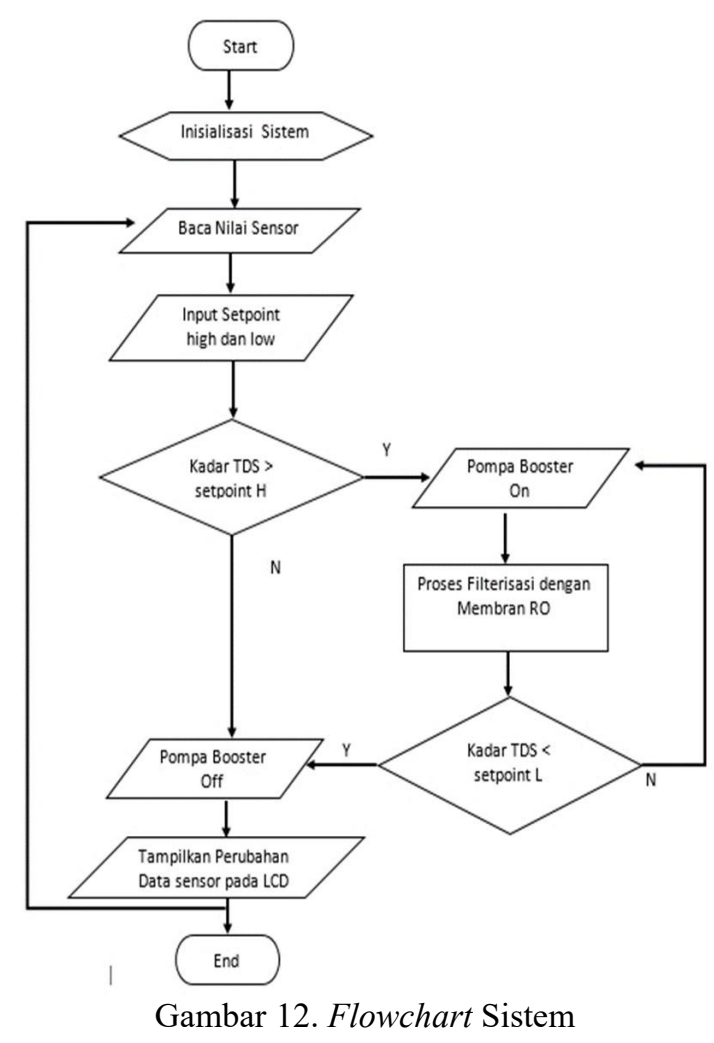

4. HASIL DAN PEMBAHASAN

\section{A. Mekanik Sistem}

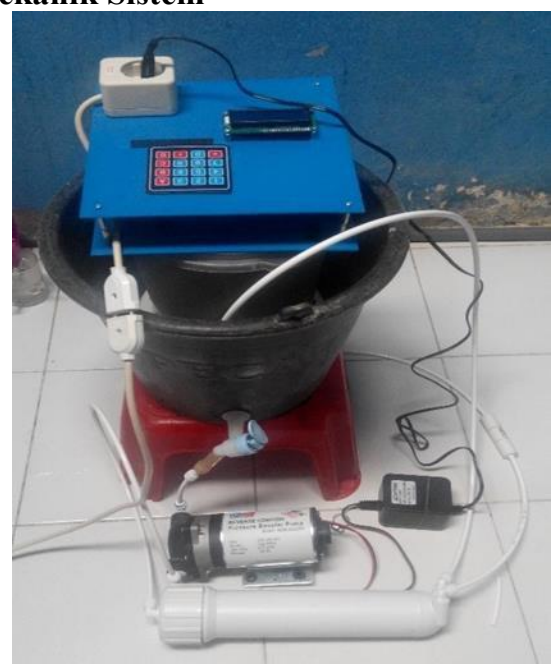

Gambar 13. Mekanik sistem

\section{B. Pengujian}

\section{Pengujian Sensor Konduktivitas}

Pengujian perbandingan nilai tegangan yang didapatkan dari sensor konduktivitas dengan nilai kadar TDS air yang diukur dengan menggunakan alat ukur TDS Meter standart. Pengujian ini dilakukan sebanyak 5 kali untuk mencari data yang nantinya akan dijadikan faktor konversi untuk sensor yang dibuat.
Tabel 4.

\begin{tabular}{|c|c|c|c|c|c|}
\hline \multicolumn{2}{|c|}{ Pengujian 1} & \multicolumn{2}{|l|}{ Pengujian 2} & \multicolumn{2}{|c|}{ Pengujian 3} \\
\hline $\begin{array}{l}\text { Tegang } \\
\text { an }\end{array}$ & $\begin{array}{l}\text { TDS } \\
\text { IPP }\end{array}$ & $\begin{array}{l}\text { Tegang } \\
\text { an }\end{array}$ & $\begin{array}{l}\text { TDS } \\
\text { (PP }\end{array}$ & $\begin{array}{l}\text { Tegang } \\
\text { an }\end{array}$ & $\begin{array}{l}\text { TDS } \\
\text { (PP }\end{array}$ \\
\hline 0.22 & 3 & 0.2 & 4 & 0. & 3 \\
\hline 0.89 & 20 & 0.9 & 2 & 0. & 20 \\
\hline 1.32 & 43 & 1.3 & 4 & 1. & 43 \\
\hline 1.41 & 53 & 1.4 & 5 & 1. & 53 \\
\hline 1.45 & 58 & 1.4 & 5 & 1. & 58 \\
\hline 1.49 & 63 & 1.5 & 6 & 1. & 63 \\
\hline 1.54 & 68 & 1.5 & 6 & 1. & 67 \\
\hline 1.59 & 73 & 1.5 & 7 & 1. & 73 \\
\hline 1.64 & 80 & 1.6 & 8 & 1. & 80 \\
\hline 1.7 & 88 & 1.7 & 8 & 1. & 87 \\
\hline 1.74 & 97 & 1.7 & 9 & 1. & 98 \\
\hline 1.79 & 10 & 1.7 & 108 & 1. & 10 \\
\hline 1.9 & 14 & 1.8 & 147 & 1. & 14 \\
\hline 2.33 & 18 & 2.3 & 189 & 2. & 18 \\
\hline 2.99 & 47 & 2.9 & 472 & 2. & 47 \\
\hline \multicolumn{2}{|c|}{ Pengujian 4} & \multicolumn{2}{|l|}{ Pengujian 5} & & \\
\hline $\begin{array}{l}\text { Tegang } \\
\text { an }\end{array}$ & $\begin{array}{l}\text { TDS } \\
\text { (PP }\end{array}$ & $\begin{array}{l}\text { Tegang } \\
\text { an }\end{array}$ & $\begin{array}{l}\text { TDS } \\
\text { (PP }\end{array}$ & & \\
\hline 0.21 & 3 & 0.22 & 3 & & \\
\hline 0.89 & 20 & 0.89 & 19 & & \\
\hline 1.33 & 43 & 1.33 & 44 & & \\
\hline 1.41 & 53 & 1.4 & 52 & & \\
\hline 1.44 & 57 & 1.46 & 59 & & \\
\hline 1.49 & 63 & 1.5 & 63 & & \\
\hline 1.54 & 69 & 1.52 & 68 & & \\
\hline 1.59 & 73 & 1.58 & 72 & & \\
\hline 1.65 & 80 & 1.64 & 79 & & \\
\hline 1.7 & 89 & 1.68 & 87 & & \\
\hline 1.75 & 98 & 1.74 & 97 & & \\
\hline 1.8 & 107 & 1.76 & 109 & & \\
\hline 1.9 & 146 & 1.88 & 146 & & \\
\hline 2.32 & 187 & 2.34 & 188 & & \\
\hline 2.99 & 471 & 3.02 & 473 & & \\
\hline
\end{tabular}

Berdasarkan data yang didapatkan di atas selanjutnya akan digunakan untuk mencari rumus konversi dari tegangan yang dikeluarkan sensor menjadi nilai TDS dalam satuan PPM, selanjutnya data yang didapatkan tersebut akan diolah dengan bantuan MATLAB menggunakan pendetakan polinomial (curve fitting) dan didapatkan persamaan sebagai berikut:

$f(x)=25.74 * x^{3}-42.97 * x^{2}+55.61 * x-9.42$

Dimana:

$\mathrm{x}=$ nilai tegangan sensor $(\mathrm{V})$

$\mathrm{f}(\mathrm{x})=$ Nilai TDS yang Terukur $(\mathrm{ppm})$

Selanjutnya dilakukan pengujian respon waktu sensor terhadap terhadap pembacaan kadar TDS air. Pengujian ini dilakukan untuk mengetahui presisi atau keakuratan alat yang dibuat, Tabel 4.3 dibawah ini merupakan hasil pengujian dari respon pembacaan sensor terhadap waktu. 
Tabel 5. Respon Sensor terhadap Waktu

\begin{tabular}{|c|c|c|c|}
\hline $\begin{array}{l}\text { Waktu } \\
\text { ke- } \\
\text { (detik) }\end{array}$ & $\begin{array}{l}\text { TDS } \\
\text { (PPM) }\end{array}$ & $\begin{array}{c}\text { Waktu } \\
\text { ke- } \\
\text { (detik) }\end{array}$ & $\begin{array}{l}\text { TDS } \\
\text { (PPM } \\
\text { ) }\end{array}$ \\
\hline 1 & 31 & 80 & 44 \\
\hline 4 & 32 & 87 & 45 \\
\hline 9 & 33 & 97 & 46 \\
\hline 17 & 34 & 107 & 47 \\
\hline 22 & 35 & 116 & 48 \\
\hline 28 & 36 & 120 & 49 \\
\hline 34 & 37 & 127 & 50 \\
\hline 40 & 38 & 136 & 51 \\
\hline 47 & 39 & 151 & 52 \\
\hline 54 & 40 & 158 & 53 \\
\hline 60 & 41 & 163 & 52 \\
\hline 65 & 42 & 180 & 53 \\
\hline 71 & 43 & & \\
\hline
\end{tabular}

Sebelum mencapai keadaan stabil nilai sensor akan berubah-rubah. Sesuai dengan pengujian yang telah dilakukan nilai sensor akan mencapai nilai stabil pada detik ke 180 seperti terlihat pada gambar 14 .

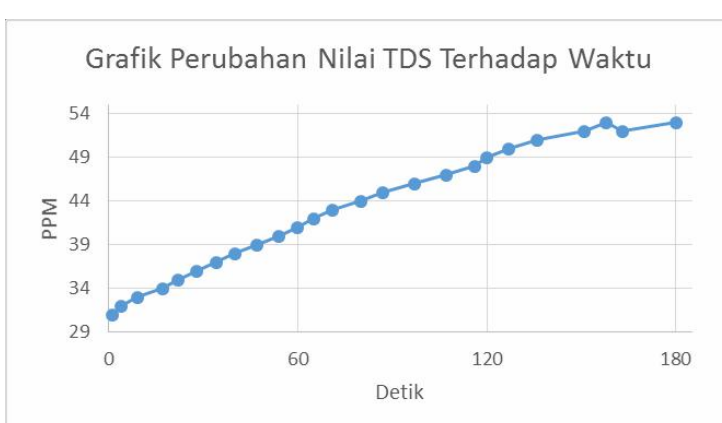

Gambar 14. Grafik Penurunan Nilai TDS terhadap Waktu

\section{Pengujian Rangkaian Keypad dan LCD}

Tabel 6. Fungsi Tobol Keypad

\begin{tabular}{|l|l|}
\hline Tombol & Fungsi \\
\hline 1 & $20-35 \mathrm{Ppm}$ \\
\hline 2 & $30-45 \mathrm{Ppm}$ \\
\hline 3 & $40-55 \mathrm{Ppm}$ \\
\hline 4 & $50-65 \mathrm{Ppm}$ \\
\hline 5 & $60-75 \mathrm{Ppm}$ \\
\hline 6 & $70-85 \mathrm{Ppm}$ \\
\hline 7 & $80-95 \mathrm{Ppm}$ \\
\hline 8 & $90-105 \mathrm{Ppm}$ \\
\hline
\end{tabular}

\begin{tabular}{|l|l|}
\hline 9 & $100-115 \mathrm{Ppm}$ \\
\hline 0 & $110-125 \mathrm{Ppm}$ \\
\hline $\mathrm{A}$ & $200-230 \mathrm{Ppm}$ \\
\hline $\mathrm{B}$ & $210-240 \mathrm{Ppm}$ \\
\hline $\mathrm{C}$ & $220-250 \mathrm{Ppm}$ \\
\hline $\mathrm{D}$ & $230-260$ Ppm \\
\hline$\#$ & $\begin{array}{l}\text { Menghapus Data } \\
\text { Setpoint }\end{array}$ \\
\hline$*$ & Reset Sistem \\
\hline
\end{tabular}

Pada tampilan utama dari sistem terdapat beberapa nilai yang ditampilkan yaitu berupa nilai setpoint high, setpoint low, nilai TDS sekarang dan status pompa yang akan berada dalam keadaan On ketika nilai TDS lebih besar dari pada nilai setpoint high serta berubah dalam keadaan Off jika nilai TDS telah kecil dari setpoint low.

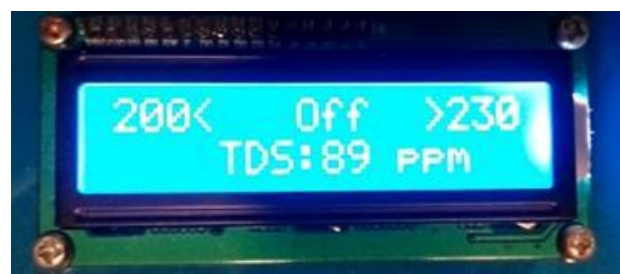

Gambar 15 Tampilan Utama Sistem

Pengujian Alat Ukur Buatan dan Alat Ukur Standar

Tabel 7. Perbandingan Kadar TDS Air Menggunakan Alat Ukur Buatan dan Alat Ukur Standar

\begin{tabular}{|l|l|l|l|}
\hline $\begin{array}{l}\text { Percobaan } \\
\text { ke - }\end{array}$ & $\begin{array}{l}\text { Alat ukur standar } \\
(\text { PPM })\end{array}$ & $\begin{array}{l}\text { Alat ukur buatan } \\
(\text { PPM })\end{array}$ & Error \\
\hline 1 & 15 & 17 & $13.3 \%$ \\
\hline 2 & 22 & 20 & $9 \%$ \\
\hline 3 & 30 & 29 & $3.33 \%$ \\
\hline 4 & 43 & 43 & $0 \%$ \\
\hline 5 & 55 & 55 & $0 \%$ \\
\hline 6 & 63 & 60 & $4.76 \%$ \\
\hline 7 & 69 & 70 & $1.45 \%$ \\
\hline 8 & 79 & 80 & $7.53 \%$ \\
\hline 9 & 93 & 100 & $2.78 \%$ \\
\hline 10 & 108 & 105 & \\
\hline
\end{tabular}

\section{Pengujian Sistem Terhadap 1 Liter Air}

Pada percobaan ini dilakukan pengujian sistem terhadap 1 liter air yang akan di turunkan kadar TDS nya dengan menggunakan membran RO dan Pompa Booster dengan rentang setpoint antara 90 $80 \mathrm{ppm}$. Berikut merupakan hasil dari pengujian yang telah dilakukan. 
Tabel 7. Respon Penurunan Kadar TDS Air Terhadap Waktu

\begin{tabular}{|l|l|l|l|l|}
\hline $\begin{array}{l}\text { Kadar TDS } \\
\text { (PPM) }\end{array}$ & $\begin{array}{l}\text { Waktu ke - } \\
\text { (Detik) }\end{array}$ & $\begin{array}{l}\text { Kadar TDS } \\
\text { (PPM) }\end{array}$ & $\begin{array}{l}\text { Waktu ke - } \\
\text { (Detik) }\end{array}$ \\
\hline 91 & 1 & & 83 & 181 \\
\hline 92 & 21 & & 81 & 218 \\
\hline 91 & 40 & & 80 & 239 \\
\hline 90 & 62 & & 79 & 260 (pompa \\
mati)
\end{tabular}

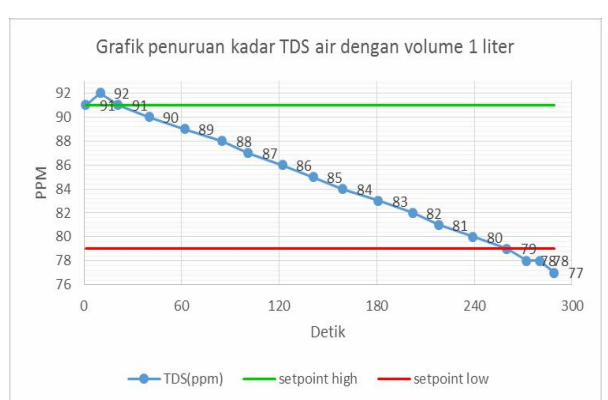

Gambar 16. Grafik Penurunan Kadar TDS Air

Berdasarkan pengujian sistem secara keseluruhan di atas yang mana kita menetapkan setpoint high sebesar 90 ppm dan setpoint low sebesar $80 \mathrm{ppm}$ dan menggunakan air sebanyak 1 liter. Seperti terlihat pada gambar 4.7 Di atas pompa hidup pada saat sensor mendeteksi nilai TDS air sebesar 91 ppm, Pada saat pengujian ketika pompa sudah hidup nilai TDS air bertambah sebesar 1 ppm menjadi 92 ppm padahal pompa telah aktif, hal ini disebabkan karena sensor membutuhkan waktu untuk mendeteksi kadar TDS menjadi lebih stabil dan tidak berubah ubah.

Sedangkan pada saat kadar TDS mencapai nilai setpoint low yaitu sebesar $80 \mathrm{ppm}$ maka pompa booster akan mati, pada saat pengujian ketika pompa booster telah mati dan sensor menunjukkan nilai TDS sebesar 79 ppm, akan tetapi kadar TDS yang terdeteksi turun mencapai 77 ppm walaupun pompa telah mati ini juga dikarenakan sensor membutuhkan waktu untuk mencapai keadaan yang stabil. Dan untuk waktu yang dibutuhkan sistem untuk menurunkan kadar TDS yakni sebesar 322 detik atau sekitar 5 menitan.
Besarnya overshoot pada pengujian ini dihitung dengan cara sebagai berikut:

$$
\begin{gathered}
\% \text { OS }=\frac{\mid \text { TDS puncak }- \text { TDS setpoint high } \mid}{\text { TDS setpoint high }} \times 100 \% \\
\% \text { OS }=\frac{92-91}{91} \times 100 \%=1.09 \%
\end{gathered}
$$

Sedangkan untuk menghitung besarnya nilai error steady state dilakukan dengan cara sebagai berikut:

$$
\begin{gathered}
\% \text { OS }=\frac{\mid \text { TDS steady }- \text { TDS setpoint low } \mid}{\text { TDS setpoint low }} \times 100 \% \\
\% \text { OS }=\frac{77-79}{79} \times 100 \%=2.53 \%
\end{gathered}
$$

\section{PENUTUP}

\section{A. Kesimpulan}

Pada penelitian ini, telah dilakukan pengujian pengukuran dan pengontrolan kadar TDS air. Berdasarkan pengujian yang telah dilakukan didapatkan error paling besar $13.3 \%$ dan nilai error terkecil sebesar $0 \%$ serta rata rata error sebesar $4.802 \%$. Pada pengujian penurunan kadar TDS air didapatkan hasil Penurunan kadar TDS air hingga mencapai setpoint dan pompa mati pada air 1 liter membutuhkan waktu sekitar 6 menit, untuk air 2 liter membutuhkan waktu sekitar 10 menit dan untuk air 3 liter membutuhkan waktu sekitar 16 menit. Semakin kecil volume air yang diuji semakin cepat pula proses penurunan kadar TDS air.

\section{B. Saran}

Setelah dilakukan penelitian, terdapat saran untuk penelitian selanjutnya, yaitu:

1. Menambahkan pengaduk kecil agar proses pembacaan kadar TDS membutuhkan waktu yang lebih sedikit.

2. Memakai membran RO dan Pompa Booster yang berkapasitas lebih besar agar penurunan kada TDS lebih cepat.

3. Sistem ini bisa dikembangkan lagi agar bisa bekerja pada skala yang lebih besar.

\section{DAFTAR PUSTAKA}

[1] J Effendi, H. 2003. Telaah Kualitas Air Bagi Pengelolaan Sumber Daya dan Lingkungan Peraian. Kanisius. Yogyakarta.

[2] Anonim. 2004, Conductivity Theory and Practice http://www.radiometer-analitycal.com /

[3] https://www.tdsmeter.com/education

[4] Anonim Tanpa Tahun, Perancangan Sistem Kontrol Total Dissolved Solid Berbasis Mikrokontroler 
http://digilib.its.ac.id/public/ITS-paper-29722-2 206100176-Paper.pdf

[5] Utomo Darmawan. 2012. Alat Pengukur Resistansi, Konduktansi dan Total Dissolved Solid Air dengan Teknik Dorang-Tarik.Techne Jurnal Ilmiah Elektronika Vol.11 No 2 Oktober 2012

[6] Dorf, Richard C. 1983. Sistem Pengaturan. Penerbit Erlangga Jakarta

[7] http://elektronika-dasar.web.id/teori-elektronika/ lcd-liquid-cristal- display/ 